\title{
26. AMMONOIDEA FROM THE LOWER CRETACEOUS OF HOLE 402A IN THE BAY OF BISCAY, DSDP LEG 48
}

\author{
Otto Renz, Museum of Natural History, Basel, Switzerland
}

\section{INTRODUCTION}

Hole $402 \mathrm{~A}$ (latitude $47^{\circ} 52.48^{\prime} \mathrm{N}$, longitude $08^{\circ} 50.44^{\prime} \mathrm{W}$ ) was drilled in a canyon on the northern mid-continental slope of the Bay of Biscay, $380 \mathrm{~km}$ west of Brest. Below 2355.5 meters of water from the rig floor the hole penetrated a sediment column of 469.5 meters, ending in lower Aptian sediments. Fourteen ammonites from the Albian-Aptian interval were collected by Prof. P.C. de Graciansky of the Ecole des Mines, Paris, and sent to the author for study. The samples containing the extremely fragile ammonite remains were slowly dried for two weeks and then sprayed with Krylon. The fossils are deposited in the Museum of Natural History in Basel under the numbers J 28489 to J 28502.

The zonal subdivision used is based on the zonal classification of ammonites from the Lower Greensand in Britain (Casey, 1961, p. 487-621).

\section{OCCURRÉNCE}

Two intervals containing ammonites can be distinguished (Figure 1). The upper interval ( 336.5 to $374.5 \mathrm{~m}$ ) represented by Cores 22 to 25 consists of dark gray, carbonaceous limey marls, with interbedded mudstone rich in mica and small detrital quartz grains. Within this interval nine samples with ammonites and one with a bivalve were revealed (Plate 1, Figures 1, 4a). In Cores 22, 24, and 25 representatives of the genus Leymeriella, restricted to the Leymeriella tardefurcata Zone, representing the lower part of the lower Albian, occur (Figure 1). Of importance is one specifically determinable specimen representing Leymeriella $(L$.$) tardefurcata$ densicostata Spath from Core 24. The genus Leymeriella is known throughout Europe, and has been studied in great detail by Jacob (1908), by Spath (1925, p. 83), and by Casey (1957).

The lower interval ( 422 to $441 \mathrm{~m}$ ), represented by Cores 31 and 32, consists of light gray brownish, chalky limestone, with small angular grains of detrital quartz. The interval yielded three ammonite species of which the youngest one from Core 31 , in spite of its very poor preservation, can be compared with Cheloniceras (Epicheloniceras) cf. martinioides Casey, indicating the $C$. martinioides Zone of the lower upper Aptian. Within the interval of Cores 26 to 30 , which is barren of ammonites, the Parahoplites nutfieldensis Zone below and the Hypacanthoplites jacobi Zone above (middle and upper upper Aptian) can be expected.

\section{CORRELATION OF DSDP HOLE 402A WITH DSDP HOLE 398D BASED ON AMMONITES}

Hole 398D (DSDP Leg 47) was drilled south of the Vigo Seamount, $90 \mathrm{~km}$ off the western coast of the Iberian

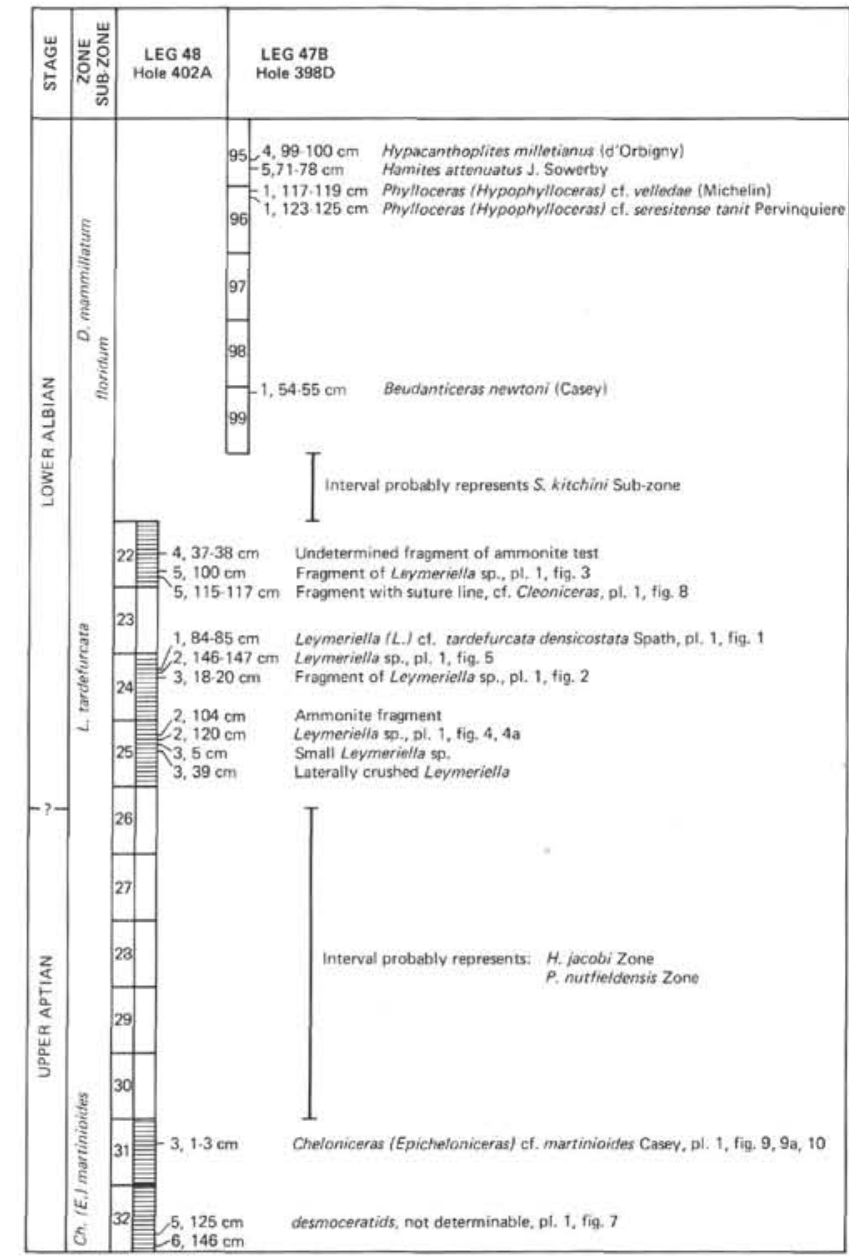

Figure 1. Correlation, based on ammonites, of lower Albian to upper Aptian of Leg 47, Hole 398D and Leg 48, Hole $402 A$.

peninsula (latitude $40^{\circ} 57.6^{\prime} \mathrm{N}$, longitude $10^{\circ} 43.1^{\prime} \mathrm{W}$ ). Cores 84 to 90 represent the Hoplites dentatus Zone (middle Albian) and Cores 83 to 99 the Douvilleiceras mammillatum Zone (upper part of the lower Albian). The $d$. Floridum Sub-zone of the $d$. Mammillatum Zone is indicated by Beudanticeras newtoni Casey in Core 99 (Renz, 1979). The interval separating Core 99 of Hole 398D from Core 22 of Hole $402 \mathrm{~A}$ can therefore be expected to represent the Sonneratia kitchini Sub-zone of the lowest $D$. mammillatum Zone (base of the Albian). 


\section{Preservation}

Preservation of the ammonites from Hole $402 \mathrm{~A}$ is comparable with that from Hole 398D. The tests are little altered diagenetically, and consist of aragonite. The outer layers, covering the prismatic layer, are whitish to light brownish, somewhat brilliant, and mother-of-pearl like. All of the shells have been crushed and flattened during compaction of the sediment; in some cases lateral compression is present, probably caused by local sliding on the continental slope. Septa of resistant phragmacones, such as those of the desmoceratides, are broken or partly bent. All specimens have their venters crushed into small fragments. By removing test fragments, suture lines appear occasionally on the internal molds (Plate 1, Figure 8).

\section{SYSTEMATIC DESCRIPTIONS}

\section{LOWER ALBIAN}

\section{Family LEYMERIELLIDAE Breistroffer, 1951}

\section{Genus LEYMERIELLA Jacob, 1907}

Leymeriella is the most common genus of the assemblage. It is restricted to Cores 22 to 25 . Seven, mostly fragmental specimens, can be allocated to this genus, but only one permits specific determination.

Leymeriella (Leymeriella) cf. tardefurcata densicostata Spath (Plate 1, Figure 1)

1957 Leymeriella (L.) tardefurcata densicostata Spath, Casey, p. 47, pl. 9 , fig. 7,7 ; pl. 10, fig. 9, 9a, 12 .

Sample $24-2,84$ to $85 \mathrm{~cm}$ (J 28489). Conch rather small. Diameter after reconstruction $25 \mathrm{~mm}$, umbilicus $8 \mathrm{~mm}, 32$ per cent of diameter. Costation on inner whorls, up to about $20 \mathrm{~mm}$ diameter, very dense. Ribs thin and sharp, crossing flank in a gently sigmoidal curve, slightly inclined forward. From about $20 \mathrm{~mm}$ diameter ribs gradually widen from below mid-flank towards venter. Ribs last exposed broadly flattened, beginning to show a median concavity (better exposed on Plate 1, Figures 2, 3, and 5).

An allocation to Leymeriella of such poorly preserved remains, exposing about 50 per cent of morphological features, is unsatisfactory. An equally flat-pressed example of a Leymeriella from the Alps in Austria is reproduced for comparison. The specimen derives from the Losensteiner Schichten in the Stiedelsbachgraben near Losenstein in the Enns valley (Kollmann, 1968), where Leymeriella is accompanied by foraminifers indicating lower Albian.

\section{Family HOPLITIDAE H. Douvillé, 1890}

\section{Subfamily CLEONICERATINAE Whitehouse, 1926}

Genus CLEONICERAS Parona and Bonarelli, 1896 (Plate 1, Figure 8)

Sample 22-5, 115 to $117 \mathrm{~cm}$ (J 28491). A fragment of test showing sigmoidal growth lines has been removed from the matrix to expose the suture line below. The external saddle between external and lateral lobes $(E$, L) was exposed. The fragment of suture coincides precisely with the corresponding segment of a Cleoniceras (compare Casey, 1966, p. 569, fig. 215).

\section{APTIAN}

Family DOUVILLEICERATIDAE Parona and Bonarelli

\section{Subfamily CHELONICERAS Spath, 1923}

Genus CHELONICERAS Hyatt, 1903

Subgenus EPICHELONICERAS Casey, 1961

Cheloniceras (Epicheloniceras) cf. martinioides Casey, 1961

(Plate 1, Figures 9, 9a, 10)

1962 Cheloniceras (Epicheloniceras) martinioides Casey, p. 239, pl. 37, fig. 1a-c, 2; pl. 38, fig. 3a, b; pl. 39, fig. 2.

Sample $31-3,1$ to $3 \mathrm{~cm}$ (J 28492). A positive and the corresponding negative impression are available. The combination of the two resulted in the sketch Figure 10 (Plate 1). Only inner whorls are preserved. Badly destroyed remains of the next outer whorl are recognizable. After reconstruction, a diameter of about $12 \mathrm{~mm}$ resulted. Umbilicus accordingly 35 per cent of diameter. On both impressions, five outstanding broad primary ribs (three on outer and two on inner whorl) are preserved. They attenuate distinctly between ventral tubercles and umbilicus. Umbilical tubercles on primary ribs not visible. Elongated lateral tubercles exposed clearly on negative as well as positive impressions. Three prominent rounded ventral tubercles on outer whorl are recognizable on both impressions. Secondary ribs, as far as preserved, are simple, sharp, with the exception of one, reaching umbilical margin.

The features exposed on the present juvenile stage coincide closely with those on juvenile Cheloniceras (E.) tschernyschiev (Sinzow) from Transcaspia, also occurring in the $S$. martinioides Zone of the Lower Greensand (compare Casey, 1962, p. 235).

\section{Family DESMOCERATIDAE Zittel, 1895}

(Plate 1, Figure 7)

Sample $32-5,125 \mathrm{~cm}$. (J 28493). A small, evolute, intensely broken desmoceratid with about eight constrictions on outer whorl. Suture not preserved.

Samples $32-5,146 \mathrm{~cm}$. (J 28494). A crushed involute ? desmoceratid without sculpture. No traces of suture.

\section{ACKNOWLEDGMENTS}

I am grateful to Mr. W. Suter, photographer of the Museum of Natural History in Basel, who did the photography.

\section{REFERENCES}

Casey, R., 1957. The Cretaceous ammonite genus Leymeriella with a systematic account of its British occurrences, Palaeontology (London), v. 1, p. 29-59. , 1961. The stratigraphical palaenontology of the Lower Greensand, Palaeontology (London), v. 3, p. 487-621. , 1962. A Monograph of the Ammonoidea of the Lower Greensand, Palaeontogr. Soc. (London), v. 4, p. 217-288. , 1966. A Monograph of the Ammonoidea of the Lower Greensand, Palaeontogr. Soc. (London), v. 7, p. 547-582.

Jacob, C., 1908. Etudes sur quelques ammonites du Crétacé moyen, Mém. Soc. Géol. France, Paléont., v. 15, p. 1-64.

Kollmann, H. A., 1968. Zur Gliederung der Kreideablagerungen der Weyerer Bögen (Ober-Oesterreich), Verh. Geol. Bundesanstalt (Wien), v. 1, p. 126-136.

Renz, O., 1979. Lower Cretaceous Ammonoidea from the northern Atlantic, Leg 47B, Hole 398D, DSDP. In Ryan, W.B.F., Sibuet, J.C., et al., Initial Reports of the Deep Sea Drilling Project, v. 47, Part 2: Washington (U.S. Government Printing Office).

Spath, L.F., 1925. A Monograph of the Ammonoidea of the Gault, Palaeontogr. Soc. . (London), v. 2. 



\section{PLATE 1}

Figure 1 Sample 24-2, 84-85 cm. (J 28489). Leymeriella (Leymeriella) cf. tardefurcata densicostata Spath. Lower Albian, L.tardefurcata Zone. Fragments of ammonite test are dispersed on surface. $2 \times$.

Figure 2 Sample 24-3, 18-20 cm. (J 28496). Fragments of Leymeriella (Leymeriella) sp., surface of test. Lower Albian, tardefurcata Zone. $2 \times$.

Figure 3 Sample 22-5, $100 \mathrm{~cm}$. (J 28497). Badly cut fragment of a Leymeriella (Leymeriella) sp., surface of test. Lower Albian, tardefurcata Zone. $2 \times$.

Figures 4, 4a Sample 25-2, 120-120.5 cm. (J 28490, J 28490a) Leymeriella (Leymeriella) sp., positive and negative impressions, surface of test. Lower Albian, tardefurcata Zone. Fragments of test densely dispersed in sediment. $2 \times$.

Figure 5 Sample 24-2, 146-147 cm. (J 28495). Fragment of Leymeriella (Leymeriella) sp., surface of test. Lower Albian, tardefurcata Zone. $2 \times$.

Figure 6 Leymeriella (Leymeriella) cf. tardefurcata (d'Orbigny), equally flattened, is reproduced for comparison (internal mold). Lower Albian, tardefurcata Zone, from Losenstein in the Austrian Alps. $1 \times$.

Figure 7 Sample $32-5,125 \mathrm{~cm}$. (J 28493). Undeterminable desmoceratid, suture line not obtainable. Aptian. $2 \times$.

Figure 8 Sample 22-5, 115-117 cm. (J 28491). Saddle between lateral and external lobus of possibly a Cleoniceras. Lower Albian, L. tardefurcata Zone. $4 \times$.

Figures 9, 9a Sample 31-3, 1-3 cm. (J 28492, J 28492a). Cheloniceras (Epicheloniceras) cf. martinioides Casey, positive and negative impressions. Upper Aptian, C. martinioides Zone. $2 \times$.

Figure 10 Sketch combining morphological features exposed on Figures 9, 9a. $4 \times$. 
PLATE 1
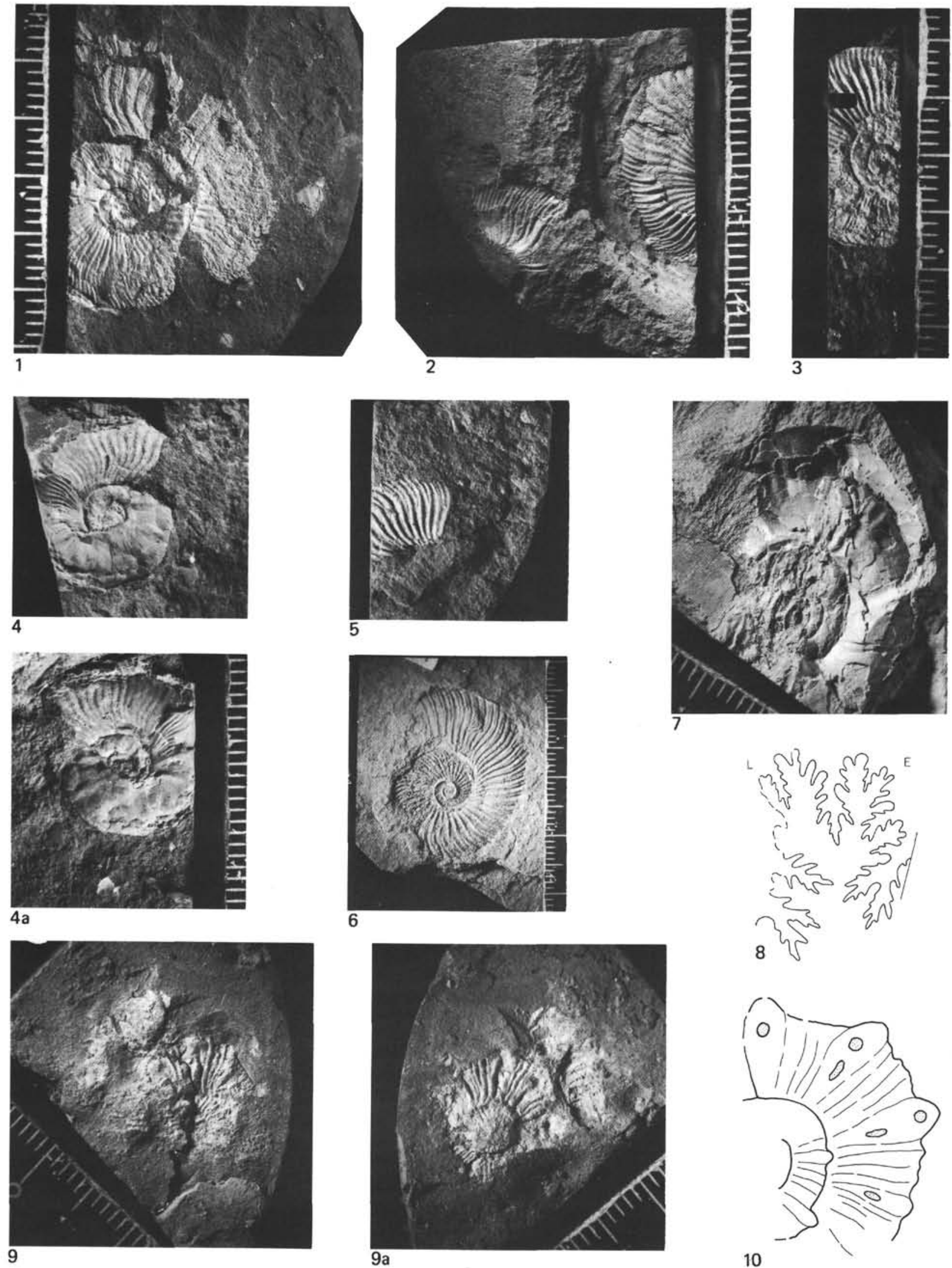